\title{
THE INSTITUTION OF CONVICTION IN THE CRIMINAL LEGISLATION OF THE REPUBLIC OF AZERBAIJAN
}

\author{
GASIMOV Aydin - doctor of Legal Sciences, professor, Dean of the Faculty of \\ Economics and Law of the Azerbaijan National Academy of Aviation \\ DOI:10.32782/NP.2020.2.7
}

\begin{abstract}
В статье указъвается, ито исследование института судимости имеет важное значение для развития теории уголовного права и для совершенствования уголовного законодательства Азербайджанской Республики.

Ключевъе слова: Кодекс, уголовнъй, право, статья, сентябрь.
\end{abstract}

Conviction is a legal consequence of a sentence imposed for a crime committed and is subject to certain criminal and other general restrictions. Explaining the definition of "conviction" is important both scientifically and practically. There are different approaches to this issue in the science of criminal law. According to Shlyapochnikov L.S. conviction is a public relationship, i.e conviction refers to the existing social relationship between the state and a person deprived of liberty [1, p. 15].

Wittenberg G.B., Bratus S.N. and Kazansev N.D. disagree with L.S. Shlyapochnikov's position that it is not known what is the content of the public relationship between the state and the imprisoned person in the criminal law sense. According to them, conviction means the situation determined by the court for the act committed by the offender [2, p. 675].

Yeraksin V.V. and Pomchalov L.F. give a more comprehensive definition of conviction, noting that conviction is a legal situation determined by the court for the act committed by the offender [3, p. 15].

According to Khan-Mammadov J.O. conviction is a restriction imposed on a person who has committed a crime for a certain period of time in connection with his place of residence and employment [4, p. 39].

According to Shautayeva G. Kh., crime, punishment, etc. are signs of of conviction [5, p. 23]. According to Agayev I.B. conviction is a spesific feature of of person's legal status. This is a legal situation caused by the fact that a person has been sentenced by a court for a crime. This situation continues from the date of entry into force of the conviction until the expiration of the period established by law [6, p. 409].

Let's look at the history of the development of criminal legislation in Azerbaijan in connection with conviction. Article 53 entitled "Conviction expungement" of the Criminal Code of the Azerbaijan SSR, consisting of 264 articles, approved by the Law of the Azerbaijan SSR of December 8, 1960 and entered into force on March 1, 1961, stated: "The following shall be deemed to have no conviction:

1) persons released from punishment, served in a disciplinary battalion or released earlier, as well as servicemen who have been sentenced in "qauptvachta" military detention instead of correctional work; persons who have served a sentence in an educational-labor institution or have been released from it prematurely;

2) probationers, provided that they have not committed a new crime during the probation period and the conditional sentence against such persons has not been revoked on other grounds provided by law within the specified period; persons sentenced to probation with compulsory labor, provided that they have 


\section{Кримінальне право, кримінальний процес та криміналістика}

not committed a new crime during the period of their compulsory employment or have not been sent to places of deprivation of liberty to serve their sentences on the grounds provided by law; Persons sentenced to imprisonment under Article 42-1 of the Criminal Code, provided that they have not committed a new crime during the period of suspension of the sentence and the sentence has not been executed in accordance with the established procedure;

3) persons sentenced to public reprimand, fine, dismissal, deprivation of the right to hold certain positions or engage in certain activities or correctional work, who have not committed a new crime within one year from the date of serving their sentence;

4) persons sentenced to imprisonment for a maximum term of three years, who have not committed a new crime within three years from the date of serving the sentence (main and additional punishment);

5) persons sentenced to imprisonment for a term exceeding three years, but not more than six years, who have not committed a new crime within five years from the date of serving the sentence (main and additional punishment);

6) persons sentenced to imprisonment for more than six years, but not more than ten years, who have not committed a new crime within eight years from the date of serving the sentence (main and additional punishment);

7) persons sentenced to imprisonment for more than ten years and especially dangerous recidivists, if they have not committed a new crime within eight years from the date of serving the sentence (basic and additional punishment) and the convict is rehabilitated and does not need to be considered a convicted person if determined by the court.

Term of conviction expungement shall be calculated from the day of serving the sentence or release from the sentence. If the sentence imposed by a court decision has been reduced or replaced by a lighter sentence under an amnesty or pardon, or due to the application of parole or unconditional early release; in this case term of conviction expungement is calculated from the time of release from serving the sentence (main and additional punishment) for the sentence actually served. If the sentence is commuted to a lighter sentence, the actual sentence shall be calculated in accordance with the rules provided for in Article 43 of the Criminal Code.

If a person sentenced to imprisonment proves that he has been rehabilitated after serving his sentence by his exemplary conduct and honest attitude to work, the court may, at the request of public organizations, remove the sentence until the expiration of the terms specified in this article.

If a convicted person commits a new crime before the expiration of the conviction expungement, the term of the conviction expungement shall be suspended. The term of conviction expungement for the first crime shall be recalculated after the sentence (principal and additional punishment) for the last crime has actually been served. In such cases, a person shall be deemed to have been convicted of both offenses until the conviction expungement for the most serious of those offenses.

If, after conviction, a law is passed that eliminates the criminality and punishment of an act committed by a person, that person shall be deemed not to have been convicted from the moment this law enters into force" [7, pp. 646647].

The Criminal Code of the Republic of Azerbaijan, in force since September 1, 2000, determines the legal significance of a conviction and the criminal consequences of its expungement and removal in accordance with the principle of legality. The legislation aims to reduce, as far as possible, the number of convicted persons and the restriction of their civil rights. Thus, Article 83 of the Criminal Code of the Republic of Azerbaijan, entitled "Conviction", gives prisoners the right to apply to the court for early removal of conviction if they prove that they were corrected by exemplary behavior after serving a sentence $[8$, p. 563].

On May 1, 2020, Article 83 of the Criminal Code of the Republic of Azerbaijan entitled "Conviction" was amended. Currently, Article 83 of the Criminal Code of the Republic of Azerbaijan states: "83.1.The person condemned for commitment of a crime shall be considered as convicted from the date of the introduction of a decision of court into validity up to the moment of removal or expungement from a previous 
conviction. The previous conviction according to the present Code shall be taken into account at relapse of crimes and at assignment of punishment.

83.2. A person who has been convicted in connection with the non-imposition of a sentence or release from the imposed sentence shall be deemed not to have been convicted.

83.3. The following cases shall be considered as expungement of conviction:

83.3.1. concerning persons conditionally condemned - in cases where there is an additional sentence that has not been served at the end of the probation period, as well as when the additional sentence has been served;

83.3.1-1. in the case of persons whose sentence has been suspended - in the event of release from punishment or unserved part of the sentence in accordance with Article 79.3 of this Code;

83.3.1-2. in respect of persons whose conviction has not been executed within the period established by law - in case of expiration of the terms provided for in Article 80.1 of this Code;

83.3.2. in the case of persons sentenced to a lighter sentence than deprivation of liberty - one year after the date of serving their sentence;

83.3.2-1. in the case of persons sentenced to imprisonment for a crime which does not pose a great public danger - one year after the day on which they have served their sentence;

83.3.3. in the case of persons sentenced to imprisonment for a less serious crime - two years after the end of their sentence;

83.3.4. concerning persons condemned to imprisonment for serious crimes - after expiration of six years from the date of serving the punishment;

83.3.5. concerning persons condemned for especially serious crimes - after expiration of eight years from the date of serving the punishment.

83.4 If condemned was prescheduled released from serving punishment or deserved part of punishment was replaced with mitigate kind of punishment provided by the law, term of conviction expungement shall be estimated from a moment of release from serving a basic and additional punishment.
83.4-1. In cases where a person who has served the main sentence, or who has been released from serving the main sentence or whose unserved part of the sentence has been replaced by a lighter sentence, has an unserved additional sentence, the term of conviction expungement shall be calculated from the day of serving the additional sentence;

83.5. If condemned after serving a punishment by good behavior will prove the correction under his petition a court may prescheduled remove a previous conviction from him.

83.6. Expungement or removal of conviction cancels all legal consequences connected to a previous conviction" [9].

As can be seen, the new Criminal Code of the Republic of Azerbaijan has abolished the rule established by the previous law substitution of the term of conviction imposed by a longterm sentence with a recidivism. This shows that the term of conviction expungement for a new crime continues. However, this shall not preclude the repeated crime as recidivism in cases provided for by law and the application of penalties for recidivism. Thus, when a conviction is expunged or revoked after the commission of a new crime, the elimination of all legal consequences related to it is applied only to the subsequent criminal relations [10, p. 196].

We consider it necessary to state that the issue of conviction is reflected in a number of decisions of the Plenum of the Constitutional Court of the Republic of Azerbaijan. For example, the Decision of the Plenum of the Constitutional Court of the Republic of Azerbaijan "On the Interpretation of Article 83.2 of the Criminal Code of the Republic of Azerbaijan" dated July 8, 2008 states that according to the Article 83.2 of the Criminal Code the person released from punishment shall be considered a person against whom a conviction has not been imposed due to the expiration of the period of criminal prosecution and who has been acquitted on the basis of an amnesty act during the trial (Article 44.2.2 of the Criminal Procedure Code of the Republic of Azerbaijan) [11].

Another example. The Decision of the Plenum of the Constitutional Court of the Republic of Azerbaijan dated May 25, 2009 "On the appeal of the Court of the Republic of Azerbaijan on Grave Crimes in connection with 


\section{Кримінальне право, кримінальний процес та криміналістика}

the interpretation of Article 83 of the Criminal Code of the Republic of Azerbaijan" states that conviction is not only conditioned by the fact that a person has been convicted and sentenced.; Conviction expresses the legal status of the convict when a convicted person commits a repeated crime causing legal consequences established by the criminal legislation; an unexpunged or unreleased conviction of a person, creates a social-legal relations formed on the basis of criminal - legal regulation between him and a Sate, which evaluates his identity and the crimes committed by him as a high social danger when committing new crimes, and therefore criminal law against him provides for the application of more severe measures .

Such measures include the imposition of penalties for a set of offenses and convictions under criminal law.

If a person is convicted of a set of crimes or sentences in accordance with Articles 83.3 and 83.4 of the Criminal Code of the Republic of Azerbaijan, the period of conviction expungement shall be calculated independently for each classification of crimes from the moment of serving the sentence or release from the sentence [12].

Another example. The Decision of the Plenum of the Constitutional Court of the Republic of Azerbaijan "On the Interpretation of Articles 18 and 83.1 of the Criminal Code of the Republic of Azerbaijan" dated September 6, 2010 states that as deliberate recidivating without expungement of conviction is evidenced by insufficient corrective effect of the previous sentence; when the purpose of the sentence was not achieved and the perpetrator's identity was highly publicly dangerous, the legislature intended to impose a more severe crime on a person" [13].

The next example. In its appeal to the Constitutional Court of the Republic of Azerbaijan, the Sheki Court of Appeal stated that by the verdict of the Zardab District Court dated September 3, 2019, V. Guliyev was found guilty under Article 234.1 of the Criminal Code and sentenced to 2 years in prison. According to Article 69.3 of the same Code, the restriction of liberty was retained over him to 1 year 5 months and 12 days.
The Deputy Prosecutor General of the Republic of Azerbaijan appealed against the verdict of the Zardab District Court dated September 3, 2019 and asked to change the verdict. The appeal was based on the fact that V. Guliyev was found guilty under Article 234.4.1 of the Criminal Code and sentenced to 7 years in prison by the Court of Grave Crimes of the Republic of Azerbaijan on February 21, 2007. On June 10, 2013, he was released from prison in accordance with paragraph 1.1 of the Resolution of the Milli Majlis of the Republic of Azerbaijan dated May 7, 2013 "On amnesty on the occasion of the 90th anniversary of the national leader of the Azerbaijani people Heydar Aliyev".

It is envisaged that the Resolution of the Milli Majlis of May 7, 2013 will come into force from the date of its publication and will be implemented within four months from that date.

According to the Prosecutor, when V. Guliyev committed the second criminal act on May 23, 2019, his previous conviction was not expunged and was not taken away. For this reason, there was recidivism in his act. Thus, in accordance with Article 18.1 of the Criminal Code of the Republic of Azerbaijan, re-offending by a person previously convicted of an intentional crime creates a recidivism of the crime.

According to Article 61.1.1 of the same Code, recidivism is an aggravating circumstance of a punishment.

According to Article 65.2 of the Criminal Code of the Republic of Azerbaijan, the term of punishment for recidivism may not be less than half of the maximum term of the more severe type of punishment specified in the relevant article of the Special Part of the Code, two thirds for dangerous recidivism and three quarters for special dangerous recidivism.

V.Guliyev was found guilty under Article 234.4.1 of the Criminal Code and sentenced to 7 years in prison by the Court of Grave Crimes on February 21, 2007 and was released from prison on June 10, 2013 in accordance with paragraph 1.1 of the Decision of the Milli Majlis.

That is, if V.Guliyev had been released on May 7, 2013, when the decision came into force, there would have been no recidivism for 
the crime committed on May 23, 2019 under Article 234.1 of the Criminal Code.

The Prosecuter considers that the period of commencement of the conviction expungement for V.Guliyev, established by Article 234.4.1 of the Criminal Code according to the verdict of the Court of Grave Crimes dated February 21, 2007, shall be calculated not from the date May 3, 2013 when the adoption of amnesty act applied to him, but from the date of execution of the amnesty act in relation to him, from June 10, 2013.

Taking into account the above-mentioned, the Sheki Court of Appeal, in order to form a unified judicial practice, asked the Consitutional Court to interpret the provision of Article 60 "if a convicted person is prematurely released from serving a sentence in accordance with the law, the term of conviction expungement shall be calculated from the time of release from serving the main and additional sentence", Articles 60 and 71 of the Consitution of the Azerbaijan Republic, as well as Articles 6 and 7 of the Convention for the Protection of Human Rights and Fundamental Freedoms, in relation to convicts released from punishment on the basis of the application of an amnesty act.

On the basis of the appeal of the Sheki Court of Appeal, the Plenum of the Constitutional Court of the Republic of Azerbaijan adopted a Decision on March 3, 2020 "On Interpretation of Certain Provisions of Article 83.4 of the Criminal Code of the Republic of Azerbaijan". In that decision, the Plenum of the Constitutional Court stated that the entry into force of the amnesty act from the date of its publication does not envisage a change in the legal status of the persons to be applied to the act from that day. The entry into force of the amnesty act indicates the time required for the determination of the scope of persons to whom the amnesty act has entered into force from the date of its publication and for the commencement of the period for which the act has entered into force.

Taking into account the above, the Plenum of the Constitutional Court stated in its decision that "in accordance with Article 83.4 of the Criminal Code of the Republic of Azerbaijan, if a convicted person is released prematurely on the basis of an amnesty act, the term of conviction expungement shall be calculated from the date of release, that is from the date of entering into force of the decision to apply the amnesty act to a specific person" [14].

We also consider it necessary to state that according to Article 174.1 of the Code of Execution of Punishments of the Republic of Azerbaijan of July 14, 2000, persons released from imprisonment, taking into account the restrictions for condemned persons established by law, enjoy the rights established for citizens of the Republic of Azerbaijan and bear responsibilities [15].

Thus, the research allows us to draw the following conclusions:

It is important to explain the definition of "conviction". A brief look at the history shows that the term conviction was not used in the first Penal Code of the Azerbaijan SSR, which came into force on February 1, 1923. During the USSR, the term conviction was first reflected in legislative acts in Article 53 of the Criminal Code of the Azerbaijan SSR of December 8,1960 . Although the article defined the range of persons deemed not to have criminal conviction, the definition of conviction was not legally defined. However, during the Soviet era, there were various definitions of conviction in the works of scholars conducting research on criminal law.

The new Criminal Code of the Republic of Azerbaijan, which came into force on September 1, 2000, further improved the norms on conviction based on the principle of legality. Thus, the new Criminal Code eliminates the rule established by the previous law on the termination of the term of imprisonment for a recidivism caused by a long sentence.

"Conviction means the legal status of a convicted in connection with a sentence against the convicted determined by a court decision that has entered into force."

We believe that in the case of persons sentenced to a lighter sentence than imprisonment, in the case of persons sentenced to imprisonment for a crime which does not pose a great public danger; as well as persons sentenced to imprisonment for less serious crimes, it would be expedient from a humanistic point of view to reduce the term of conviction expungement.

Guided by these views, we propose that Articles 83.3.2, 83.3.2-1 and 83.3.3 of the 


\section{Кримінальне право, кримінальний процес та криміналістика}

Criminal Code of the Republic of Azerbaijan shall be amended to read as follows:

„83.3.2. in the case of persons sentenced to a lighter sentence than deprivation of liberty six months after the date of serving their sentence;

83.3.2-1. in the case of persons sentenced to imprisonment for a crime which does not pose a great public danger - six months after the day on which they have served their sentence;

83.3.3. in the case of persons sentenced to imprisonment for a less serious crime - one year after the end of their sentence;

\section{Bibliographic references}

1. Шляпочников А.С. Советская юстиция // Орган НКЮ РСФСР: ОГИЗ. - М.: Советское законодательство, 1936, № 22, с. 1516

2. Юридический словарь / Главный редактор С.Н.Братусь и др. Москва: Госюриздат, 1953, $781 \mathrm{c.}$

3. Ераксин В.В., Помчалов $\lambda$. Ф. Погашение и снятие судимости в советском уголовном праве. Москва: Изд-во МГУ, 1963, $48 \mathrm{c}$.

4. Хан-Магомедов Д.О. Освобождения от наказания по советскому праву: лекция / Под ред. Ю.И.Аяпунова. М.: Высшая школа МООП РСФСР, 1964, 47 с.

5. Шаутаева Г.Х. Судимость в уголовном праве России и ее правовое значение : дис. ... канд. юр.наук. Ижевск, 2000, 213 с.

6. Ağayev İ.B. Azərbaycan Respublikasının Cinayət hüququ. Bak1: Nurlar, 2010, 832 s. [In Azerbaijani].

7. Almanax. Cinayət qanunları külliyyatı (1920-2000). Bakı: Hüquq Yayın Evi, 2014, 1184 s. [In Azerbaijani].

8. Səməndərov F.Y.Cinayət hüququ: Ümumi hissə. Dərslik. Bakı: Digesta, 2013, 720 s. [In Azerbaijani].

9. Azərbaycan Respublikasının Cinayət Məcəlləsində dəyişiklik edilməsi haqqında 01 may 2020-ci il tarixli Azərbaycan Respublikasının Qa-

\section{SUMMARY}

The article indicates that the study of the institution of record of conviction is important for the development of the theory of criminal law and for improving the criminal legislation of the Republic of Azerbaijan

Key words: Code, criminal, law, article, september.

nunu. https://president.az/articles/38731 [In Azerbaijani].

10. Azərbaycan Respublikas1 Cinayət Məcəlləsinin kommentariyas1 / F.Y.Səməndərovun redaktəsi ilə. Bakı: Digesta, 2012, 1104 s. [In Azerbaijani].

11. Azərbaycan Respublikas1 Konstitusiya Məhkəməsi Plenumunun «Azərbaycan Respublikas1 Cinayət Məcəlləsinin 83.2-ci maddəsinin şərh olunmasına dair»08 iyul 2008-ci il tarixli Qorarı. Bak1, «Azərbaycan» qəzeti, 09 iyul 2008-ci il. [In Azerbaijani].

12. Azərbaycan Respublikası Konstitusiya Məhkəməsi Plenumunun «Azərbaycan Respublikası Cinayət Məcəlləsinin 83-cü maddəsinin şərh olunması ilə bağlı Ağır cinayətlərə dair işlər üzrə Azərbaycan Respublikası Məhkəməsinin müraciətinə dair» 25 may 2009-cu il tarixli Qərarı. Bak1, «Azərbaycan» qəzeti, 26 may 2009-cu il. [In Azerbaijani].

13. Azərbaycan Respublikası Konstitusiya Məhkəməsi Plenumunun «Azərbaycan Respublikas1 Cinayət Məcəlləsinin 18-ci və 83.1-ci maddələrinin şərh edilməsinə dair» 06 sentyabr 2010-cu il tarixli Qərarı. http://www.constcourt.gov.az/searchdecision [In Azerbaijani].

14. "Azərbaycan Respublikas1 Cinayət Məcəlləsinin 83.4-cü maddəsinin bəzi müddəalarının şərh edilməsinə dair" Azərbaycan Respublikası Konstitusiya Məhkəməsi Plenumunun 03 mart 2020-ci il tarixli Qərarı. http://www.constcourt.gov.az/decision/1120 [In Azerbaijani].

15. Azərbaycan Respublikasının 14 iyul 2000ci il tarixli Cəzaların İcrası Məcəlləsi. http://www.eqanun.az/code/15 [In Azerbaijani]. 